\title{
Expression of Concern to: Downregulation of NIN/RPN12 binding protein inhibit the growth of human hepatocellular carcinoma cells
}

\author{
Zaiming $\mathrm{Lu}^{1} \cdot$ Qiyong Guo ${ }^{1} \cdot$ Aizhong Shi ${ }^{1} \cdot$ Feng Xie $^{1} \cdot$ Qingjie Lu $^{1}$
}

Published online: 2 April 2021

(c) Springer Nature B.V. 2021

\section{Correction to: Molecular Biology Reports (2012) 39:501-507 https://doi.org/10.1007/s11033-011-0764-8}

The Editor-in-Chief would like to alert readers that this article [1] includes a problematic cell line. After further analysis, SMMC-7721 is shown to be a HeLa derivative (https:// www.ncbi.nlm.nih.gov/pubmed/28807831). Because of this, readers are asked to interpret the results with caution.

None of the authors have responded to any correspondence from the editor about this editorial expression of concern.

\section{Reference}

1. Lu Z, Guo Q, Shi A et al (2012) Downregulation of NIN/RPN12 binding protein inhibit the growth of human hepatocellular carcinoma cells. Mol Biol Rep 39:501-507. https://doi.org/10.1007/ s11033-011-0764-8

Publisher's Note Springer Nature remains neutral with regard to jurisdictional claims in published maps and institutional affiliations.

The original article can be found online at https://doi.org/10.1007/ s11033-011-0764-8.

Qiyong Guo

qiyongguo@yahoo.cn

1 Department of Radiology, China Medical University

Shengjing Hospital, 36 Sanhao Street, Heping District,

Shenyang 110004, Liaoning Province, China 